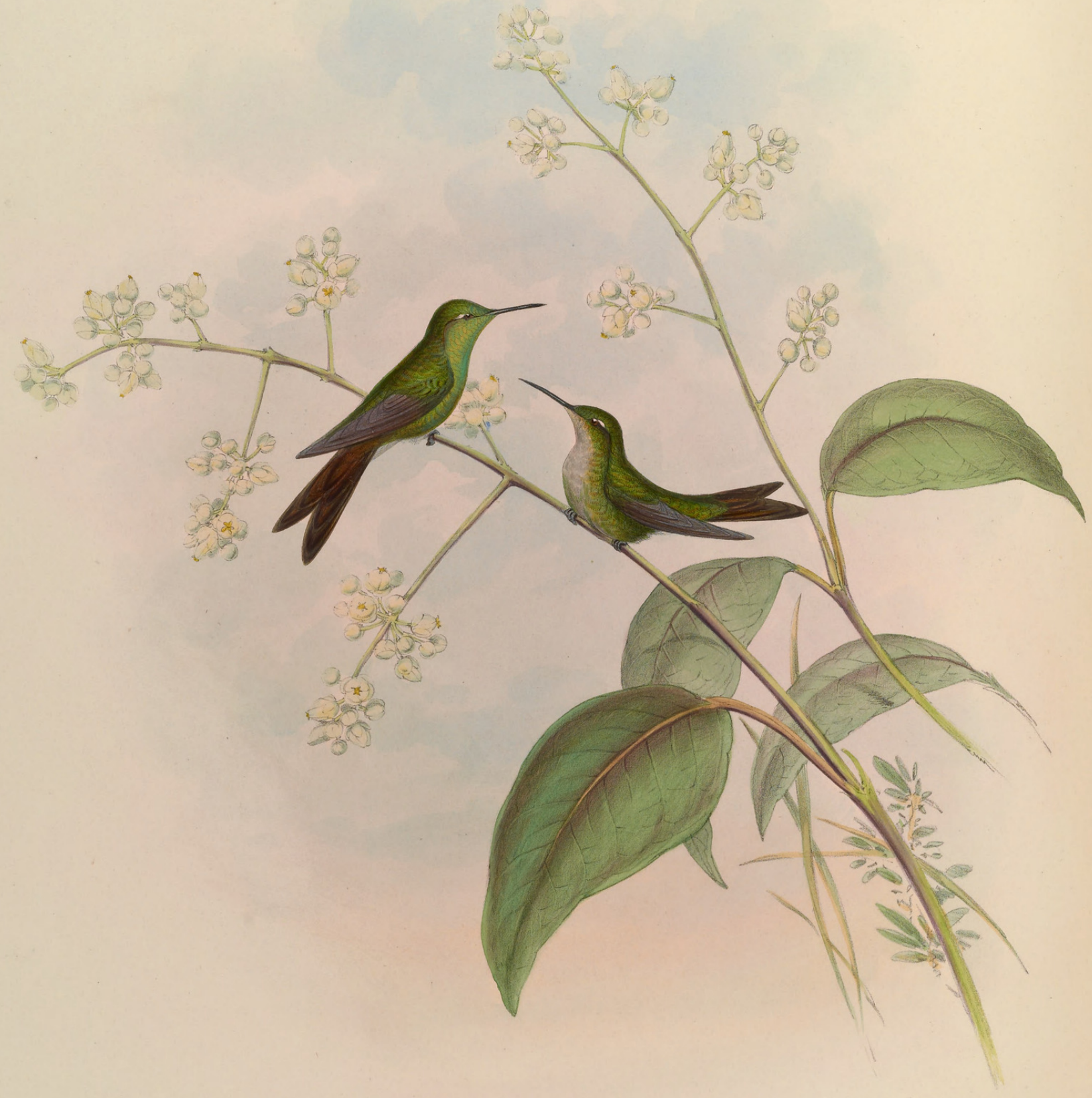




\title{
SPORADINUS RICCORDI.
}

\section{Riccord's Humming-Bird.}

\author{
Orthorhynchus Ricordi, Ramon de la Sagra, Hist. de Cuba, p. 128. tab. 21. fig. 2. \\ Ornismya Parzudhaki, Less. Rev. Zool. 1838, p. 315. \\ Sporadinus ricordi, Bonap. Rev. et Mag. de Zool. 1854, p. 255. \\ Hylocharis Ricordi, Gray and Mitch. Gen. of Birds, vol. i. p. 114, Hylocharis, sp. 23. \\ Trochilus ricordi, Grev. Mag. de Zool. 1835, Ois., pls. 41, 42.-Bonap. Consp. Gen. Av., p. 81, \\ Trochilus, sp. 2. \\ Riccordia Raimondi, Reichenb. Auf. der Col., p. 8. \\ Chlorestes riccordii, Gundl. in Cab. Journ. für Orn. 1856, tom. iv. p. 99.
}

I HAVE frequently had occasion to remark how limited are the areas affected by some species of this great group of birds, many being confined to even the smallest of the West Indian Islands; indeed, most of those islands are tenanted by species peculiar to each, and Cuba is not an exception to the rule,-two, at least, of the species which fly there are not to be found elsewhere. Besides being remarkable for the limited extent of its habitat, this species is rendered conspicuous by differing in structure from (with one exception) all the other members of the family; this difference of structure, however, is only appreciable by the Trochilidist and those who have paid much attention to the subject. The differences referred to principally consist in the long and forked form of the tail, and the peculiar shape of the feathers of which it is composed,-features which are found in one other species only, the Sporadinus elegans, a bird inhabiting the island of St. Domingo.

I have great pleasure in extracting a short note from the 'Journal für Ornithologie,' a publication of great merit and interest, issued by our German coadjutors under the superintendence of the learned ornithologist, M. Cabanis. The note is, I believe, from the pen of Dr. Gundlach, who states that the Sporadinus Riccordi is " a very common bird on the island of Cuba, which it never leaves throughout the year. I have found fresh-laid eggs in January, May, and September. I once found a nest that had probably served the same bird for years; it was, in this case, a nest built upon an old one, and, after this operation had been repeated for five or six nests, the whole structure had turned over on one side, a new nest had been built upon it, and a second again upon this. They nest, as I said above, almost throughout the year. The eggs of each brood are two in number, white, and are set upon for fourteen days before the young appear ; when the latter come out of the eggs they are black, with some bright down upon the back. The very short diminutive beak, which is then rather broad than long, is whitish."

The following note respecting this species is from the pen of M. Alcide D'Orbigny, and is to be found in M. Ramon de la Sagra's 'Histoire de Cuba,' p. 29 :-

"Far from migrating, like the Red Humming-Bird (Trochilus colubris), this is one of the stationary inhabitants of the island of Cuba, which it never leaves, and of which it is one of the most beautiful ornaments. The inhabitants (to imitate, doubtless, the sound which it makes whilst flying) give it the name of Zun-Zun. Interesting in its plumage and habits, its works are likewise not without merit. Artificially built, and often composed of wool from the silk which surrounds the seed of Asclepias anasarica, its nest is attached to the forks of young twigs; like that of all the Trochilidæ, it contains only one or two eggs, from which the young are produced, who, at their birth, have the beak very short."

Much difference occurs in the colouring of the sexes of this bird, but in form they are very similar, - the female having the same peculiarity in the shape of the tail.

For the loan of the fine female from which my figure of that sex was taken, I am indebted to the liberality of my friend M. Bourcier of Paris, my own collection not being graced with one; neither, so far as I am aware, is there one in any other collection in this country.

The entire plumage of the body of the male is bronzy green, the bronzy hue predominating on the head, and the green becoming very luminous on the throat and under surface; wings purplish brown; four central tail-feathers dark bronze, the remainder dark purplish black, glossed with bronze on their outer webs; under tail-coverts white, with a streak of brown down the centre; bill dark brown, except at the base of the under mandible, which appears to have been reddish.

The female has the crown of the head brown; all the upper surface, wing-coverts, tail-coverts, sides of the neck and flanks bronzy green; wings purplish brown; tail as in the male, but the bronzy hue somewhat greener; throat and centre of the abdomen pale buff; under tail-coverts buffy white.

The Plate represents both sexes of the size of life. The plant is the Lacepedea insignis. 


\section{$2 \mathrm{BHL}$ Biodiversity Heritage Library}

Gould, John. 1861. "Sporadinus ricordi, Riccord's Humming-Bird. [PI. 348]." A monograph of the Trochilidae, or family of humming-birds 5, https://doi.org/10.5962/p.317157.

View This Item Online: https://www.biodiversitylibrary.org/item/108806

DOI: https://doi.org/10.5962/p.317157

Permalink: https://www.biodiversitylibrary.org/partpdf/317157

\section{Holding Institution}

Smithsonian Libraries

\section{Sponsored by}

Smithsonian Institution Libraries

\section{Copyright \& Reuse}

Copyright Status: NOT_IN_COPYRIGHT

This document was created from content at the Biodiversity Heritage Library, the world's largest open access digital library for biodiversity literature and archives. Visit BHL at https://www.biodiversitylibrary.org. 